\title{
GOING BACK FOR HITLER
}

\section{The perils of time travel.}

\section{BY GEORGE NIKOLOPOULOS}

$\mathrm{K}$ illing Hitler has long been the Holy Grail of time travellers. Every now and again some determined soul goes back in time to try, but all fail. It seems that Lady Time is fiercely protective of her strands and our actions are but proverbial ripples in the pond.

I may be young and frowned upon by my supposedly more knowledgeable colleagues, but I sincerely believe I have found the solution in Doctor Jablonski's papers. Entropy diligently thwarts those who actively attempt to change the past, he proposed, but if one goes with the flow, so to speak, they might be able to act in small ways, thereby precipitating big changes.

As most time travellers realize, this is clearly an impossible situation. If you go back in time with the express purpose of changing the past, you will most definitely do it willingly. That's where my own humble contribution lies, and that's why I will succeed where everyone else has failed. I'm just about to erase my memories and travel back in time innocent as a newborn babe.

I have read everything about the monster. I know all his crimes and all his atrocities by heart; you could even say that I have brainwashed myself. It's all burnt into my mind, so deep that even after wiping my memory clean some vestige will remain, buried in the recesses of my unconscious. I won't even know that I come from the 'future', but I will be subconsciously drawn to him and - although oblivious of the reason - I will hate him enough to kill him.

I know the price to pay; unaware that there's a present to go back to, I will remain stranded in the past, a hapless amnesiac. This will not stop me; my sense of purpose is so strong that I would gladly sacrifice everything to succeed.

I sit in the time machine's seat and strap myself in. I set the timer to go off in ten minutes. Off to 1913, a reasonable choice, as he should be much easier to kill before he comes to power, and I don't think I could bring myself to kill a child. I inject myself with the memory-wiping serum - and then I wait. And I wait.

A blinding light. Where am I? Who am I?

ONATURE.COM Follow Futures: y @NatureFutures f go.nature.com/mtoodm
Standing on an open field next to a wide road, the wind ruffling my hair, I can't

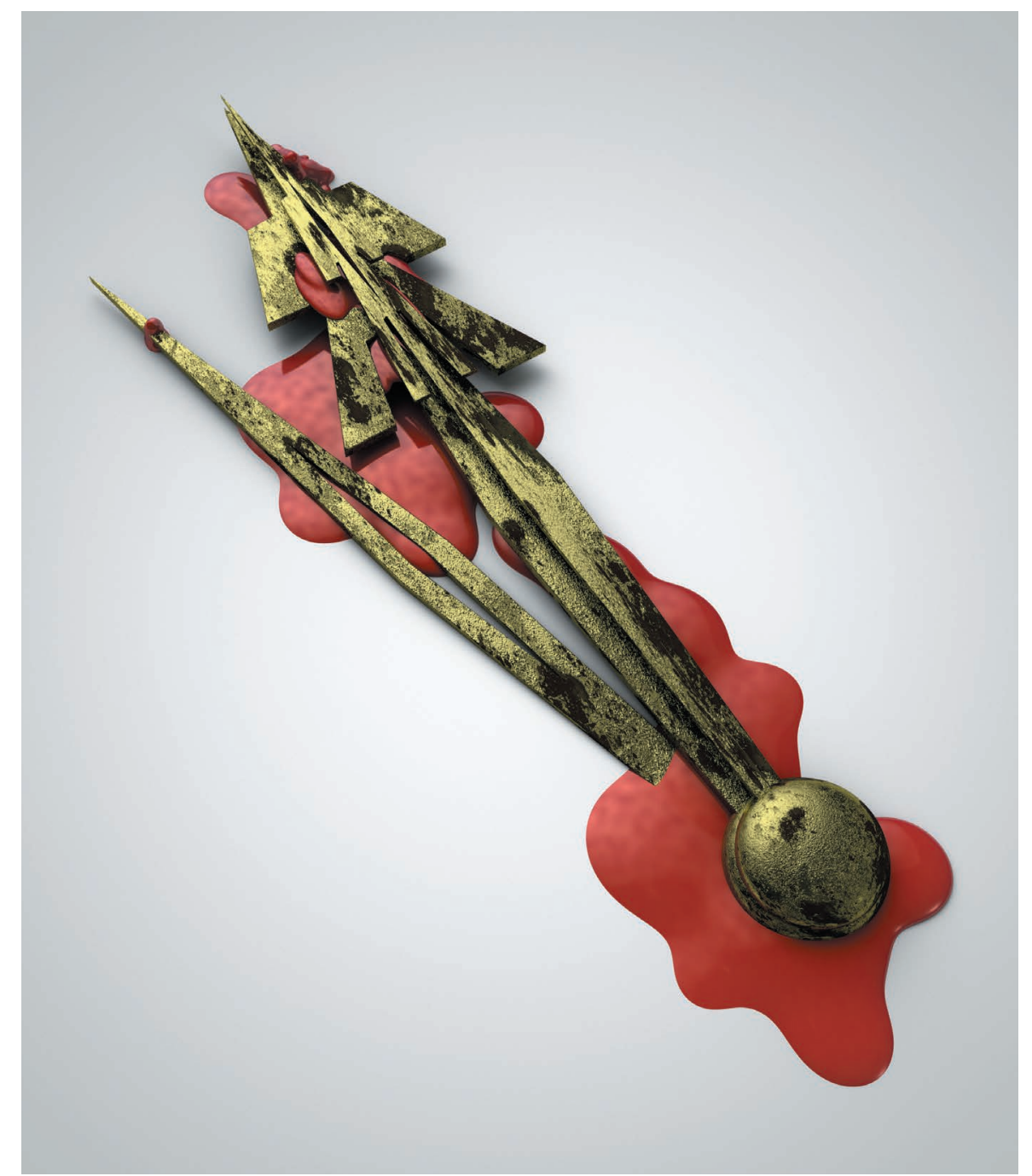

remember who I am but I know I have a glorious purpose in life. It feels both frightening and exhilarating.

I hear a faint moaning sound from down the road and I move towards it. The road turns abruptly to the left to cross a thicket of trees. As I enter the wood, I see an overturned automobile. One of the wheels lies a little farther down the road; it must have come off as the car turned the bend.

The moaning comes from inside the car. Filled with apprehension, I open the door to see a young man lying in a pool of blood. There's an ugly wound in his left temple.

"Water, please," he whispers when he sees me.

"I'm sorry, I have none," I tell him. "Try to hang on, I'll go for help."

He clasps my hand. "I'm going to Munich," he says. He coughs blood. "I'm a painter."
He's struggling to speak; then his eyes roll and he dies.

I rummage through his sack and find his papers. His name was Adolf Hitler.

I say it loudly. It has a nice ring to it; it even sounds vaguely familiar.

There's money in his wallet. I put it in my pocket. On a whim, I also take his papers. I lacked a name and now I have one. A name and a sense of purpose. I have a feeling that people will talk about me in years to come.

As I say the name again, weird, unnatural, terrible visions come unbidden to my mind. Is this to be my destiny? I shiver with fear or anticipation.

George Nikolopoulos is a speculative fiction writer from Greece. His stories have been published in Galaxy's Edge, Factor Four, Best Vegan SFF 2016 and elsewhere. 